\title{
Research on EMC Management Model in Environmental Protection Field
}

\author{
Yi Lin \\ Business School, Nanfang College of Sun Yat-Sen University, Guangzhou, China
}

Email: moniquelin@126.com

Keywords: EMC mode; energy saving; environmental protection industry

\begin{abstract}
In order to promote the future development of the environmental protection industry by using energy conservation and environmental protection mechanisms, contract energy management was introduced into the environmental protection industry. First, the concept of contract energy management was introduced. Then, taking the $\mathrm{M}$ corn starch factory as an example, the specific application of the EMC mechanism in the field of environmental protection was studied. Finally, the EMC management model in China's environmental protection field was proposed. The results showed that this model achieved a win-win situation for both energy conservation and environmental protection, and further promoted the research of EMC management model. Therefore, the close integration of energy conservation and environmental protection industries has practical significance for promoting the development of China's environmental protection industry.
\end{abstract}

\section{Introduction}

The EMC management model is the main obstacle to the market to resolve the macroeconomics of the market [1]. Contract energy management is a market-oriented energy-saving model. It originated in the 1970s and has been around for more than 30 years. In countries with highly developed economies, the application of EMC management has matured [2]. However, in today's society, the world promotes energy conservation and environmental protection. This EMC model has begun to attract the attention of the Chinese government and it has been applied to specific projects. Among them, the fields of construction and industry are the main areas of application [3]. This model has a series of services such as diagnostic design, procurement and mid-to-late service, which reduces the cost of energy paid by customers to pay for project investment.

\section{Construction of EMC model in environmental protection industry}

\subsection{Energy efficiency analysis mode}

The entire investment and transformation risks of energy-saving projects are burdened by energy-saving companies [4]. After the project is completed, the energy conservation company and the energy-using unit determine the energy-saving ratio according to the contract. Then, according to the energy saving ratio, the energy saving benefits after the transformation are shared. After the term of the project contract is over, the energy conservation company transfers the ownership of the equipment purchased by the renovation project to the energy-using unit. The property rights of the equipment and the energy-saving benefits formed by the subsequent energy-saving renovation projects are owned by the energy-using units [5]. This model is first carried out by energy-saving companies in the form of loans to banks, and the cost of financing is relatively high. This type of energy-saving company bears a greater risk when it comes to retrofitting. According to the relevant principles, the cost of big risks is also very large. During the contract period, the price of energy or the energy saving benefits of the transformation changed [6]. The investment costs of energy-saving companies have also changed, and the benefits have also changed. It may even bring losses. This is the most common mode in China at present. 


\subsection{Energy guarantee mode}

The funds and risks of energy-saving renovation projects are burdened by energy-saving companies. During the contract period, the company promises some energy-saving quantities to the energy-using units, or bears some expenses. The cost will be saved to cover the cost. The part that does not reach the agreed amount is borne by the company [7]. The excess is shared by both parties. During the contract period, the property rights of the added energy-saving equipment belong to the company and are managed by energy-saving companies. After the contract period, the property rights of the equipment will be owned by the enterprise, and the energy-saving benefits generated will be enjoyed by the enterprise [8]. The energy saving guarantee model has a relatively large risk. Therefore, mature and energy-efficient technologies are often adopted.

\section{Actual project analysis under EMC mode}

\subsection{Introduction of the $M$ corn starch plant project}

The M plant uses corn as a raw material to produce corn starch and sell it to the outside world. 200,000 tons of corn starch is processed each year. The wastewater treatment capacity is $3000 \mathrm{t} / \mathrm{d}$. Because the company did not establish a supporting sewage treatment facility, the wastewater was directly discharged into the municipal water network. $M$ factory has not met the relevant standards for the current production status, so it is modified to meet the production needs.

The company's existing production wastewater quality was measured. The wastewater reuse rate is low and the unit displacement is large. At the same time, the company's raw materials use corn as a raw material to produce starch. The production wastewater is treated by simple precipitation. Therefore, the concentration of pollutants in the drainage is lower than that of the general starch wastewater. According to the wastewater production situation of most domestic starch production industries, combined with the production process and the measured results, the wastewater discharge water quality of general starch production enterprises is given, as shown in Table 1.

Table 1 The wastewater quality of starch production (unit: mg/L)

\begin{tabular}{|c|c|c|c|c|}
\hline Item & COD & BOD & TSS & Ammonia nitrogen \\
\hline $\begin{array}{c}\text { Measured corn starch } \\
\text { wastewater }\end{array}$ & 6577 & 3336 & 527 & 100 \\
\hline $\begin{array}{c}\text { Domestic similar } \\
\text { production enterprises }\end{array}$ & $6000-15000$ & $2400-6000$ & $1000-5000$ & $20-100$ \\
\hline $\begin{array}{c}\text { General starch wastewater } \\
\text { quality }\end{array}$ & 10000 & 6000 & 3000 & 100 \\
\hline
\end{tabular}

Table 2 Comparison of returns of technical transformation of the project and full commission of energy conservation

\begin{tabular}{|c|c|c|}
\hline Number & $\begin{array}{l}\text { When the company itself makes technical } \\
\text { renovations to the project }\end{array}$ & $\begin{array}{l}\text { When the energy conservation service company } \\
\text { makes technical renovations to the project }\end{array}$ \\
\hline 1 & Take full investment & Zero investment \\
\hline 2 & Take huge risks & Zero risk \\
\hline 3 & Full management & Free management, one-stop service \\
\hline 4 & $\begin{array}{l}\text { Not professional enough and incapable of } \\
\text { improving energy savings }\end{array}$ & $\begin{array}{l}\text { More scientific, standardized, professional, pay } \\
\text { attention to energy savings }\end{array}$ \\
\hline 5 & $\begin{array}{l}\text { Bear the employee's salary and daily operating } \\
\text { expenses of the project }\end{array}$ & $\begin{array}{c}\text { No need to bear the salary of the management staff } \\
\text { and the daily operation and management expenses of } \\
\text { the project }\end{array}$ \\
\hline 6 & Enjoy all the energy saving benefits & $\begin{array}{l}\text { Enjoy some energy-saving benefits during the } \\
\text { contract period, obtain ownership and profit-making } \\
\text { rights during the contract period, and enjoy all } \\
\text { energy-saving benefits. }\end{array}$ \\
\hline
\end{tabular}


The concentration of COD and BOD in the wastewater of the M corn starch plant is relatively high. After anaerobic plus aerobic secondary biochemical treatment, secondary emission standards can be achieved. At the same time, organic matter in water can be decomposed into methane and carbon dioxide. This type of wastewater treatment mode can be used in EMC mode. The energy conservation company serves the $\mathrm{M}$ starch plant in project design, auditing, project construction and installation.

The $\mathrm{M}$ factory's technical transformation of this project and the revenues of the discretionary energy-saving company are shown in Table 2.

\subsection{Implementation plan of EMC management technology}

Wastewater treatment process: The $\mathrm{M}$ corn starch plant was technically modified. After investigation, the EGSB+activated sludge tank + air flotation treatment process was used for wastewater treatment.

Wastewater treatment effect: According to the removal rate of pollutants given by the technical unit, the treatment effect of the wastewater treatment process is shown in Table 3. As can be seen from the data in the table, such a process is used to treat wastewater from the $\mathrm{M}$ corn starch plant. The treatment was carried out by "EGSB reactor, denitrification reaction + activated sludge tank". A denitrification reaction is added to the organic matter treatment. The final discharged wastewater can meet the secondary emission standards of the Integrated Wastewater Discharge Standard. The process adds a treatment of the air flotation cell, and the wastewater treated by the air flotation cell can reach the first-class discharge standard.

Table 3 The wastewater treatment process and its effect of EGSB+ activated sludge wastewater treatment process and its effect

\begin{tabular}{|c|c|c|c|c|c|}
\hline Process section & Item & COD & BOD & SS & $\begin{array}{c}\text { Ammonia } \\
\text { nitrogen }\end{array}$ \\
\hline \multirow{3}{*}{ Initial sink } & Influent & 10000 & 6000 & 3000 & \multirow{3}{*}{100} \\
\hline & effluent & $<9000$ & $<500$ & $<1500$ & \\
\hline & Removal rate & $>10 \%$ & $>17 \%$ & $>50 \%$ & \\
\hline \multirow{3}{*}{ EGSB reactor } & Influent & 9000 & 5000 & 1500 & \multirow{3}{*}{100} \\
\hline & effluent & $<900$ & $<400$ & $<900$ & \\
\hline & Removal rate & $>90 \%$ & $>92 \%$ & $>40 \%$ & \\
\hline \multirow{3}{*}{$\begin{array}{l}\text { Denitrification } \\
\text { reactor }+ \\
\text { activated sludge } \\
\text { tank }\end{array}$} & Influent & 900 & 400 & 900 & 100 \\
\hline & effluent & $<150$ & $<30$ & $<100$ & $<8$ \\
\hline & Removal rate & $>83 \%$ & $>93 \%$ & $>89 \%$ & $>92 \%$ \\
\hline \multirow{3}{*}{$\begin{array}{l}\text { Air floatation } \\
\text { pool }\end{array}$} & Influent & 150 & 30 & 100 & \multirow{3}{*}{8} \\
\hline & effluent & $<100$ & $<20$ & $<70$ & \\
\hline & Removal rate & $>33 \%$ & $>33 \%$ & $>30 \%$ & \\
\hline
\end{tabular}

Biogas power generation plan: According to the specific conditions of wastewater treatment, in order to reduce the expenditure on treatment and increase economic benefits, biogas is used to generate electricity. This strategy is in line with China's policy on establishing a circular economy for environmental protection. This time, the 500GF1-1RZ generator was used. The power generation process is shown in Figure 1. 


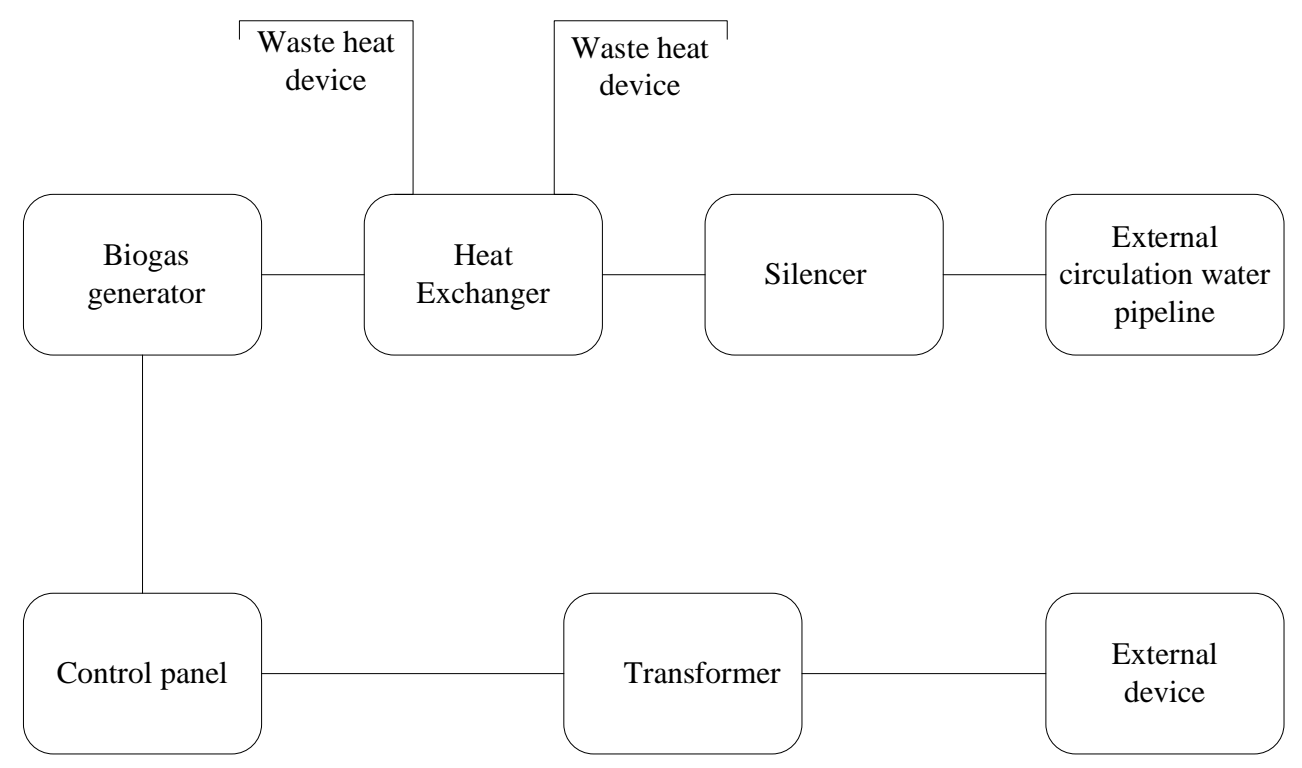

Figure 1 Diagram of open type power plant

\subsection{Project feasibility analysis}

Investment Estimation: This energy-saving project is mainly a transformation of wastewater treatment and power generation projects. The budget table is shown in Table 4.

Table 4 The budget table of energy saving renovation project

\begin{tabular}{|c|c|c|}
\hline Number & Item & Cost (ten thousand yuan) \\
\hline 1 & Wastewater treatment & 250 \\
\hline 2 & Biogas power generation & 136.5 \\
\hline 3 & Liquidity & 25 \\
\hline Total & - & 412.5 \\
\hline
\end{tabular}

Specific implementation: Total funds: This energy-saving renovation requires a total capital of 4.125 million yuan. Among them, fixed assets investment in wastewater treatment and biogas power generation were 2.5 million yuan and 1.365 million yuan respectively. The liquidity fund is 250,000 yuan.

Source of funds: All funds come from bank loans.

Project planning: If the entire project is completed by December 2018, the renovation project will be completed from December 2017 to December 2018 and passed the acceptance. The normal service life of the reconstruction project is 15 years. If the energy saving company and the $\mathrm{M}$ factory reach a contract, the contract period is five years. From the beginning of 2019 to 2024, the energy-saving companies in these five years will use the energy-saving income of the $\mathrm{M}$ plant as the total income. After five years, the profit and ownership of the renovation project is owned by the $\mathrm{M}$ plant.

Economically feasible analysis: $\mathrm{M}$ plant power generation revenue: The designed plant wastewater volume of the $\mathrm{M}$ plant is $3000 \mathrm{t} / \mathrm{d}$. The amount of biogas produced per day is about 8,900 cubic meters, and the amount of methane in the biogas is about $60-70 \%$. If electricity is used, biogas per cubic meter can generate $2.5 \mathrm{kwh}$, and the electricity generated per day is $22250 \mathrm{kwh}$. The electricity price was 0.5 yuan, and the electricity cost of the generator was calculated at 0.12 yuan. If the calculation is based on 310 days a year, the annual power generation revenue is: (0.5$0.12) * 22250 * 310=262.105$ million.

Residual heat utilization benefits: The project uses a thermoelectric system. After the relevant calculations, one unit can generate $1 \mathrm{MPa}$ of steam per year. 1125t of hot-gas was generated. The 
heat per ton is calculated as 100 yuan, and the residual heat benefit is 11.25 million yuan.

The cost of sewage treatment: According to the local sewage treatment standards, if the enterprise does not have sewage treatment facilities, the sewage charges will be charged at 0.8 yuan per ton. If the enterprise has sewage treatment facilities and the sewage discharge reaches the standard, the sewage charge will be charged at 0.12 yuan. Before the energy-saving renovation, the daily sewage charges of the enterprise are: $3000 \mathrm{t} / \mathrm{d} * 0.8$ yuan*310=744,000 yuan. After the project was reformed, the sewage discharge reached the city standard. Therefore, the annual processing fee is $3,000 \mathrm{t} / \mathrm{d} * 0.12$ yuan*310=1126 million yuan. In this case, the renovation project saved 74.4$11.26=63.24$ million yuan for the M plant every day.

Taking the wastewater treatment capacity of $\mathrm{M}$ plant as $3000 \mathrm{t} / \mathrm{d}$ as an example, the treatment cost of wastewater is 255,500 yuan. Combined with the above analysis, the renovation project was analyzed. The analysis results are shown in Table 5:

Table 5 The before and after of the transformation on the total cost estimates

\begin{tabular}{|c|c|c|}
\hline Number & Item & Cost (ten thousand yuan) \\
\hline 1 & Wastewater treatment operating costs & -25.95 \\
\hline 2 & Biogas power generation benefit & 262.105 \\
\hline 3 & $\begin{array}{c}\text { Biogas power generation and waste } \\
\text { heat recovery benefits }\end{array}$ & 11.25 \\
\hline 4 & Save sewage treatment fees & 63.24 \\
\hline Total & - & 310.54 \\
\hline
\end{tabular}

Benefit analysis:

Total annual revenue of renovation project $=$ power generation benefit - waste heat recovery benefit - wastewater operation cost $=2.473$ million yuan

Project recovery period $=$ total investment $/$ total annual income $=412.5 / 247.3=1.66$ years

The above is based on the analysis of all the energy-saving benefits generated by the energysaving company's energy-saving renovation within the contract period. After the renovation project is put into operation, the energy-saving company can recover all the initial investment after one and a half years. Within 3.5 years, the investment income of the $\mathrm{M}$ plant was acquired. For M plants, energy-saving projects do not require investment. Five years after the completion of the renovation project, the ownership of the equipment and the benefits after the energy-saving transformation can be recovered. The goal of zero investment + no risk + long-term profit is realized. In addition, it can save the relevant sewage treatment fee of 632,400 yuan. According to the specific circumstances of the project, the energy conservation company and the $\mathrm{M}$ plant can set their respective revenue share ratios in the contract to optimize the results of the income allocation. This allows both parties in the contract to obtain a more appropriate distribution of benefits and increase the enthusiasm of EMC management.

\section{Conclusion}

The relevant content of EMC management was introduced. Through the relevant exploration of the wastewater modification project of $\mathrm{M}$ plant, the feasibility of contract energy management is illustrated. The implementation of some environmentally-related projects can be carried out in a combination of EMC management. In the field of environmental protection, a new market-based mechanism such as contract energy management was introduced. The benefit distribution relationship between energy-using companies and energy-saving companies is optimized. Enterprises and energy-saving companies achieve a win-win situation in environmental protection and energy conservation projects. This has positive significance for the establishment of environmental awareness. At the same time, the energy-saving renovation project has played a positive role in promoting the development of China's environmental protection cause and the establishment of the emerging contract energy management method. 


\section{References}

[1] Liu Y, Bralts V F, Engel B A. Evaluating the effectiveness of management practices on hydrology and water quality at watershed scale with a rainfall-runoff model. Science of The Total Environment, 2015, 511: 298-308.

[2] Ryu J, Jang W S, Kim J, et al. Development of field pollutant load estimation module and linkage of QUAL2E with watershed-Scale L-THIA ACN model. Water, 2016, 8(7): 292.

[3] Baek S S, Choi D H, Jung J W, et al. Optimizing low impact development (LID) for stormwater runoff treatment in urban area, Korea: Experimental and modeling approach. Water research, 2015, 86: 122-131.

[4] Groulx M, Lemieux C, Dawson J, et al. Motivations to engage in last chance tourism in the Churchill Wildlife Management Area and Wapusk National Park: the role of place identity and nature relatedness. Journal of Sustainable Tourism, 2016, 24(11): 1523-1540.

[5] Li T, Bai F, Han P, et al. Non-point source pollutant load variation in rapid urbanization areas by remote sensing, Gis and the L-THIA model: A case in Bao'an District, Shenzhen, China. Environmental management, 2016, 58(5): 873-888.

[6] Liang D, Liu T. Does environmental management capability of Chinese industrial firms improve the contribution of corporate environmental performance to economic performance? Evidence from 2010 to 2015. Journal of cleaner production, 2017, 142: 2985-2998.

[7] Lucke T, Drapper D, Hornbuckle A. Urban stormwater characterisation and nitrogen composition from lot-scale catchments-New management implications. Science of the Total Environment, 2018, 619: 65-71.

[8] Caldas A L D, Lima E M C, Carvalho J A, et al. Management of irrigation at different stages phenological Cayenne pepper grown in protected environment. Revista Brasileira de Agricultura Irrigada, 2016, 10(2): 553-564. 